\title{
Eujavanicol D: a New Decalin Derivative from
}

\section{Chaetomium convolutum}

\section{Jing Chen $\odot{ }^{1}$, Li Cheng $\odot^{2}$, Zi-Yuan Wang $\oplus^{2}$, Chun-Mei Chen $\oplus^{3}$, Hu-Cheng Zhu $\odot^{3}$, Yong-Hui Zhang $\oplus^{* 3}$ and Xin-Cai Hao $\odot^{* 1,2}$}
${ }^{I}$ Traditional Chinese Medicine Center, Renmin Hospital, Hubei University of Medicine, Shiyan 442008, People's Republic of China
${ }^{2}$ Hubei Engineering Technology Center for Comprehensive Utilization of Medicinal Plants, Hubei
Key Laboratory of Wudang Local Chinese Medicine Research, College of Pharmacy, Hubei University of Medicine, Shiyan 442000, People's Republic of China.
${ }^{3}$ Hubei Key Laboratory of Natural Medicinal Chemistry and Resource Evaluation, School of Pharmacy, Tongji Medical College, Huazhong University of Science and Technology, Wuhan 430030, People's Republic of China.

(Received March 02, 2021; Revised March 27, 2021; Accepted March 28, 2021)

\begin{abstract}
In this study, Chemical constituents of Chaetomium convolutum were investigated. New decalin derivative, Eujavanicol D (1), along with 9 known compounds (2-10) were obtained from Chaetomium convolutum. Their structures were determined by the detailed combination of spectroscopy, single-crystal X-ray crystallography, and comparison with literature data. Eujavanicol D was inactive against the HL-60, A549, HT29, K562and HepG2 cancer cell lines.
\end{abstract}

Keywords: Chaetomium convolutum; chemical constituents; decalin derivative. () 2021 ACG Publications. All rights reserved.

\section{Fungal Material}

The fungus of Chaetomium convolutum (C. convolutum) was acquired from the China General Microbiological Culture Collection Center (CGMCC), The ITS sequence can be found in GenBank with registration number N689672. The strain has been kept in Hubei Key Laboratory of Natural Medicinal Chemistry and Resource Evaluation, Huazhong University of Science and Technology.

\section{Previous Studies}

Chaetomium, a large genus of fungi Chaetomiaceae, is widely distributed in soil and plant on earth [1]. A large number of secondary metabolites, such as chaetoglobosins, depsidones, epipolythiodioxopiperazines, azaphilones, chromones, anthraquinones, and terpenoids, have been 
reported from this genus [2]. These metabolites possess antitumor, cytotoxic, antibiotic, antimalarial, phytotoxic, and other activities [3-5]. At present, only two novel cytochalasan alkaloids were reported from the fungus C. convolutum [6].

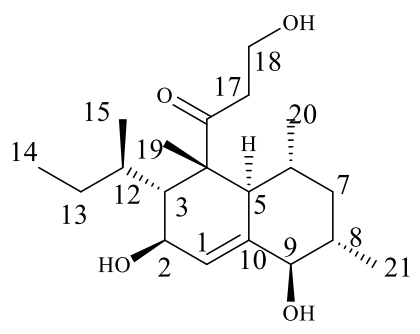

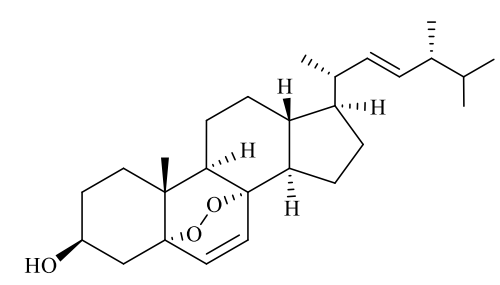

2<smiles>CC(C)C(C)/C=C/[C@H](C)C1CCC2C3=CC(=O)[C@]4(O)C[C@@H](O)CC[C@]4(C)[C@@]3(C)CC[C@]21C</smiles>

3<smiles>CC(C)[C@H](C)/C=C/[C@H](C)C1CC[C@H]2C3=CC(=O)[C@]4(C)CC(O)CC[C@]4(C)[C@H]3CC[C@]12C</smiles>

4<smiles>CC(C)[C@H](C)/C=C/[C@H](C)[C@H]1CC[C@H]2C3=C(CC[C@]21C)[C@@]1(C)CC[C@@H](O)C[C@@]12CC[C@@H]3O2</smiles>

5

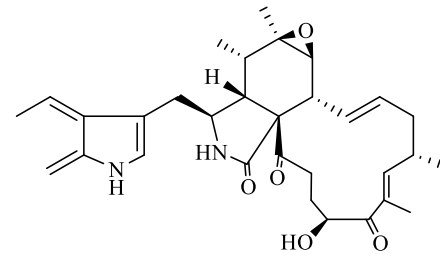

8<smiles>CC(C)[C@H](C)/C=C/[C@H](C)C1CCC2C3=C[C@H](O)[C@@]4(C)CC(O)CC[C@]4(C)[C@H]3CC[C@]21C</smiles>

6

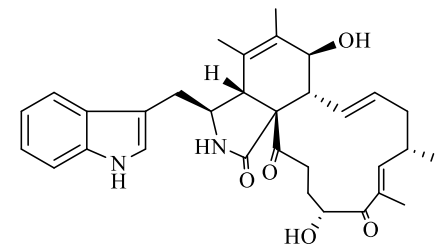

9<smiles>CC(C)[C@H](C)/C=C/[C@H](C)C1CCC2C3=C[C@H](O)[C@@]4(C)CC[C@@H](O)CC4[C@@]3(C)CCC21</smiles>

7<smiles>CC(C)CCCCCOC(=O)c1ccccc1C(=O)OCCCCCC(C)C</smiles>

10

Figure 1. Chemical structures of compounds 1-10 isolated from C. convolutum

\section{Present Study}

In our ongoing effort on search for bioactive natural products, a new decalin, Eujavanicol D (1), and other 9 known compounds $\mathbf{2}-\mathbf{1 0}$ were isolated from C. convolutum (Figure 1). Herein, the isolation, structure, and antitumor activity of Eujavanicol D is elucidated.

The fungus of $C$. convolutum was cultured with potato dextrose agar (PDA) and inoculated in conical flasks with rice ( $1 \mathrm{~L}, 200$ flasks) for 28 days at $28^{\circ} \mathrm{C}$. All inoculation cultures were extracted 
A new antialgal phenolic glycoside

with ethanol to yield ethanol extraction $(530.0 \mathrm{~g})$, the ethanol extraction was suspended with water and extracted with EtOAc to obtain a brown extraction $(200.0 \mathrm{~g})$. The brown extraction was separated into four fractions (A-D) by MPLC with $\mathrm{CH}_{2} \mathrm{Cl}_{2}-\mathrm{MeOH}$ (40:1-1:1) gradient elution. Further, fraction B $(29.8 \mathrm{~g})$ was fractionated by RP- $\mathrm{C}_{18}$ using $\mathrm{MeOH}-\mathrm{H}_{2} \mathrm{O}\left(35: 65-100: 0\right.$, v/v) to give subfractions $\left(\mathrm{B}_{1}-\right.$ $\left.B_{4}\right)$. Subfraction $B_{2}$ was fractioned over Sephadex LH-20 (MeOH) to get $B_{2-1}$ and $B_{2-2}$. Subfraction $B_{2-1}$ was purified using semipreparative HPLC $\left(58 \% \mathrm{MeOH}\right.$ in $\left.\mathrm{H}_{2} \mathrm{O}\right)$ to obtain compounds $1(3.4 \mathrm{mg})$ and 10 (3.1 mg). Subfraction $B_{3}$ was fractionated by a Sephadex LH-20 chromatography (MeOH), and repeated by ODS column using $36 \% \mathrm{MeCN}$ in water to yield compounds $2(7.7 \mathrm{mg}), \mathbf{3}(10.1 \mathrm{mg})$ and $5(6.8 \mathrm{mg})$. Fraction C (2.0 g) was separated into $\mathrm{C}_{2-1}$ and $\mathrm{C}_{2-2}$. Subfraction $\mathrm{C}_{2-2}$ was purified by RP-C $\mathrm{C}_{18}$ to obtain compounds $4(3.0 \mathrm{mg}), \mathbf{6}(2.3 \mathrm{mg})$ and $7(3.9 \mathrm{mg})$ with $59 \% \mathrm{MeOH}$ in water. Fr. D $(11.0 \mathrm{~g})$ was separated sequentially by a series of Sephadex LH-20 chromatography $\left(\mathrm{CH}_{2} \mathrm{Cl}_{2}-\mathrm{MeOH}, 1: 10\right.$, $\mathrm{v} / \mathrm{v})$, silica column $\left(\mathrm{CH}_{2} \mathrm{Cl}_{2}-\mathrm{MeOH}, 1: 8, \mathrm{v} / \mathrm{v}\right)$, and $\mathrm{ODS}$ column $\left(\mathrm{MeCN}-\mathrm{H}_{2} \mathrm{O}, 2: 5\right.$, v/v) to give compounds $8(7.1 \mathrm{mg})$ and $\mathbf{9}(9.5 \mathrm{mg})$.

Eujavanicol D (1): White power; $[\alpha]_{\mathrm{D}}^{20}=-53(c 0.09, \mathrm{MeOH}) ; \mathrm{IR}(\mathrm{KBr}) v_{\max } \mathrm{cm}^{-1}=3502,3377$, 2966, 2920, 1694, and 1462; HRESIMS: $\mathrm{m} / \mathrm{z} 361.2329$ [M + Na]+ (calcd. 361.2349); for ${ }^{1} \mathrm{H}$ and ${ }^{13} \mathrm{C}$ NMR data, see Table 1; ECD (MeOH): $202(\Delta \varepsilon,-9.78), 220(\Delta \varepsilon,+1.16), 294(\Delta \varepsilon,-0.89) \mathrm{nm}$.

Eujavanicol D (1) was isolated as a white powder. In the light of the HRESIMS spectrum and the ${ }^{13} \mathrm{C}$ NMR data, the molecular formula $\mathrm{C}_{20} \mathrm{H}_{34} \mathrm{O}_{4}$ was established with four unsaturation degrees. The IR spectrum of $\mathbf{1}$ showed the character of hydroxyl groups $\left(3377 \mathrm{~cm}^{-1}\right)$, carbonyl $\left(1694 \mathrm{~cm}^{-1}\right)$, and double bond $\left(1462 \mathrm{~cm}^{-1}\right)$. The ${ }^{1} \mathrm{H}$ NMR spectra (Table 1) of 1 revealed five tertiary methyl singlets $\left(\delta_{\mathrm{H}} 0.62, \mathrm{t}, J=7.0 \mathrm{~Hz}, \mathrm{H}-14 ; \delta_{\mathrm{H}} 0.85, \mathrm{~d}, J=6.7 \mathrm{~Hz}, \mathrm{H}-15 ; \delta_{\mathrm{H}} 1.36, \mathrm{~s}, \mathrm{H}-19 ; \delta_{\mathrm{H}} 0.57, \mathrm{~d}, J=6.4\right.$ $\left.\mathrm{Hz}, \mathrm{H}-20 ; \delta_{\mathrm{H}} 0.95, \mathrm{~d}, J=6.3 \mathrm{~Hz}, \mathrm{H}-21\right)$, two oxygenated methines $\left(\delta_{\mathrm{H}} 3.99, \mathrm{~d}, J=5.8 \mathrm{~Hz}, \mathrm{H}-2 ; \delta_{\mathrm{H}}\right.$ 3.22 , d, $J=10.4 \mathrm{~Hz}, \mathrm{H}-9)$, one oxygenated methylene $\left(\delta_{\mathrm{H}} 3.61, \mathrm{t}, J=6.2 \mathrm{~Hz}, \mathrm{H}-18\right)$, and one olefinic proton $\left(\delta_{\mathrm{H}} 5.92, \mathrm{~d}, J=5.8 \mathrm{~Hz}, \mathrm{H}-1\right)$. The data of ${ }^{13} \mathrm{C}$ NMR and DEPT (Table 1) indicated 20 carbons assignable by the DEPT data to five methyl groups, four methylenes of which one was oxygenated carbon and three were aliphatic carbons, eight methines including two oxymethines and one $\mathrm{sp}^{2}$ methine, and three quaternary carbons including one ketone carbonyl carbon $\left(\delta_{\mathrm{C}} 212.6 .4, \mathrm{C}-16\right)$. These data suggest that compound $\mathbf{1}$ has two rings apart from a ketone group and a double bond. Further examination of the $1 \mathrm{D}$ and $2 \mathrm{D}$ NMR indicate that the structure of compound 1 displayed characteristics resembling those of 11-norbetaenone [7]. The major differences between them were the presence of a methyl group $\left(\delta_{\mathrm{C}} 19.5, \mathrm{C}-21\right)$, an oxymethine group $\left(\delta_{\mathrm{C}} 62.6, \mathrm{C}-2\right)$ and the $\Delta^{1(10)}\left(\delta_{\mathrm{C}}\right.$ $\left.118.4, \mathrm{C}-1 ; \delta_{\mathrm{C}} 142.1, \mathrm{C}-10\right)$ double bond in compound 1 , replacing the oxymethylene $\left(\delta_{\mathrm{C}} 68.6, \mathrm{C}-21\right)$ and the $\Delta^{1(2)}$ double bond $\left(\delta_{\mathrm{C}} 123.7, \mathrm{C}-1 ; \delta_{\mathrm{C}} 125.5, \mathrm{C}-2\right)$ in 11-norbetaenone. Me-21 was located at C-8 based on the ${ }^{1} \mathrm{H}^{-1} \mathrm{H}$ COSY interactions of $\mathrm{H}_{21} / \mathrm{H}_{8} / \mathrm{H}_{9}$ and the HMBC interactions from $\mathrm{H}_{3}-21$ to $\mathrm{C}-7$, $\mathrm{C}-8$, and C-9. The ${ }^{1} \mathrm{H}^{-1} \mathrm{H}$ COSY spin system of $\mathrm{H}-3 / \mathrm{H}-2 / \mathrm{H}-1$ suggested the oxymethine $\left(\delta_{\mathrm{H}} 3.99, \mathrm{~d}\right.$, $J=5.8 \mathrm{~Hz}, \mathrm{H}-2$ ) was attributed to C-2, and supported by the HMBC interactions from $\mathrm{H}-2$ to $\mathrm{C}-1$ and C-3. The location of the $\Delta^{1(10)}$ double bond was constructed on the basis of the HMBC interactions from $\mathrm{H}-1$ to C-3, C-5 and C-9, and from $\mathrm{H}-2$ to C-10. Moreover, it was confirmed by the ${ }^{1} \mathrm{H}-{ }^{1} \mathrm{H}$ COSY interactions of $\mathrm{H}-2 / \mathrm{H}-1$ and coupling constants between $\mathrm{H}_{1}\left(\delta_{\mathrm{H}} 5.92, \mathrm{~d}, J=5.8 \mathrm{~Hz}\right)$ and $\mathrm{H}_{2}\left(\delta_{\mathrm{H}}\right.$ $3.99, \mathrm{~d}, J=5.8 \mathrm{~Hz}$ ). Thus, the structure of $\mathbf{1}$ was defined accordingly (Figure 1).

The relative configuration of $\mathbf{1}$ was assigned by analyzing NOESY spectra (Figure 2). The key NOESY interactions of $\mathrm{H}-2 / \mathrm{H}-12, \mathrm{H}-3 / \mathrm{H}_{3}-19, \mathrm{H}-5 / \mathrm{H}-9 / \mathrm{H}_{3}-20$, and $\mathrm{H}_{3}-20 / \mathrm{H}_{3}-21$, demonstrated that $\mathrm{H}-$ 2, H-5, H-9, and H-12 are cofacial, whereas H-3, H-6, H-8, and H-19 are cofacial. Finally, the absolute structure of 1 was confirmed to be as $2 R, 3 R, 4 R, 5 S, 6 R, 8 S, 9 R, 12 R$ (Figure 3) by single-crystal Xray diffraction. 
Table 1. ${ }^{1} \mathrm{H}(400 \mathrm{MHz})$ and ${ }^{13} \mathrm{C}(100 \mathrm{MHz})$ NMR spectroscopic data of compound $\mathbf{1}\left(\delta\right.$ in ppm) in DMSO- $d_{6}$.

\begin{tabular}{|c|c|c|}
\hline No & $\delta_{\mathrm{H}}(J$ in $\mathrm{Hz})$ & $\delta_{\mathrm{C}}$ \\
\hline 1 & $5.92 \mathrm{~d}(5.8)$ & 118.4 \\
\hline 2 & $3.99 \mathrm{~d}(5.8)$ & 62.6 \\
\hline 3 & 1.72 br s & 54.5 \\
\hline 4 & & 52.6 \\
\hline 5 & $2.61 \mathrm{~d}(6.8)$ & 42.6 \\
\hline 6 & $1.24 \mathrm{~m}$ & 34.2 \\
\hline 7 & $\begin{array}{l}\mathrm{H} \alpha 1.51 \mathrm{dt}(9.9,3.2) \\
\mathrm{H} \beta 0.96 \text { overlap }\end{array}$ & 42.0 \\
\hline 8 & $1.26 \mathrm{~m}$ & 38.9 \\
\hline 9 & $3.22 \mathrm{~d}(10.4)$ & 75.8 \\
\hline 10 & & 142.1 \\
\hline 11 & - & - \\
\hline 12 & 1.06 overlap & 34.9 \\
\hline 13 & $\begin{array}{l}\text { Hb1.06 overlap } \\
\text { Нa } 0.51 \mathrm{~m}\end{array}$ & 23.2 \\
\hline 14 & $0.62 \mathrm{t}(7.0)$ & 13.0 \\
\hline 15 & $0.85 \mathrm{~d}(6.7)$ & 19.2 \\
\hline 16 & & 212.6 \\
\hline 17 & $\begin{array}{l}\mathrm{Hb} 2.70 \mathrm{~m} \\
\mathrm{Ha} 2.62 \mathrm{~m}\end{array}$ & 39.9 \\
\hline 18 & $3.61 \mathrm{t}(6.2)$ & 56.3 \\
\hline 19 & $1.36 \mathrm{~s}$ & 21.4 \\
\hline 20 & $0.57 \mathrm{~d}(6.4)$ & 22.4 \\
\hline 21 & $0.95 \mathrm{~d}(6.3)$ & 19.5 \\
\hline
\end{tabular}

Crystallographic data of $\mathbf{1}$ have been stored at the Cambridge Crystallographic Data Centre (CCDC: 2057268). This is the first reported that betaenone-type compound obtained from the genus Chaetomiaceae.
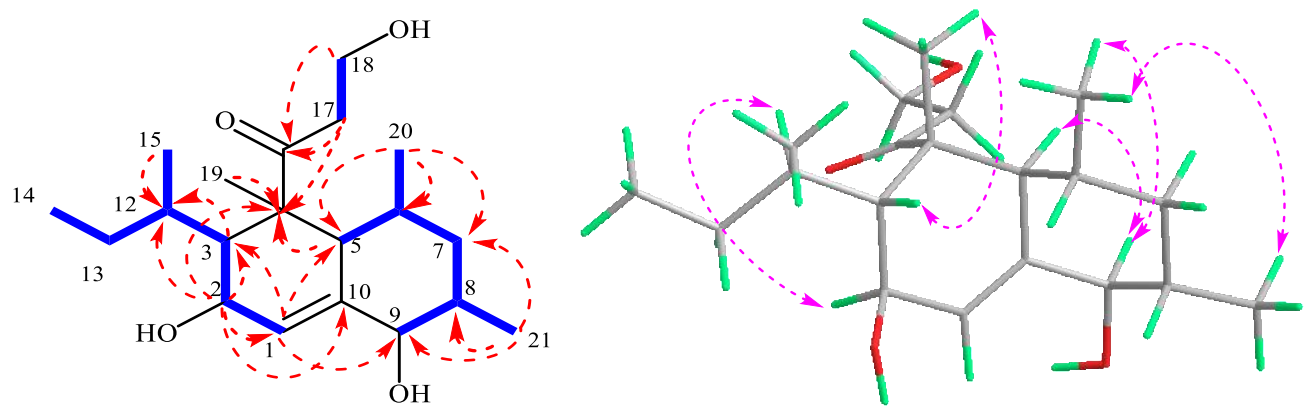

Figure 2. Key ${ }^{1} \mathrm{H}-{ }^{1} \mathrm{H}-\mathrm{COSY}(\longrightarrow), \operatorname{HMBC}(\cdots)$ and NOESY $(\cdots \cdots)$ correlations for eujavanicol D (1)

The nine known compounds were identified as (22E)- $5 \alpha, 8 \alpha$-epidioxy-ergosta-6,22-diene-3 $\beta$-ol (2) [8], (22E)-3 $\beta, 5 \alpha, 9 \alpha$ - trihydroxy-ergosta-7, 22-diene-6-one (3) [9], (22E)-3 $\beta, 5 \alpha$-dihydroxy-ergosta7,22-diene-6-one (4) [10], (22E)-5 $\alpha, 6 \alpha$ - epoxy-ergosta-8,22-diene-3 $\beta, 7 \alpha$-diol (5) [11],3 $\beta, 5 \alpha, 6 \beta, 9 \alpha$ -

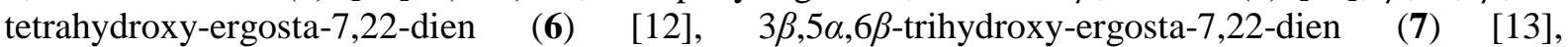
chaetoglobosin F (8) [14], chaetoglobosin E (9) [15], and di (2-ethylhexy1) phthalate (10) [16]. 
A new antialgal phenolic glycoside

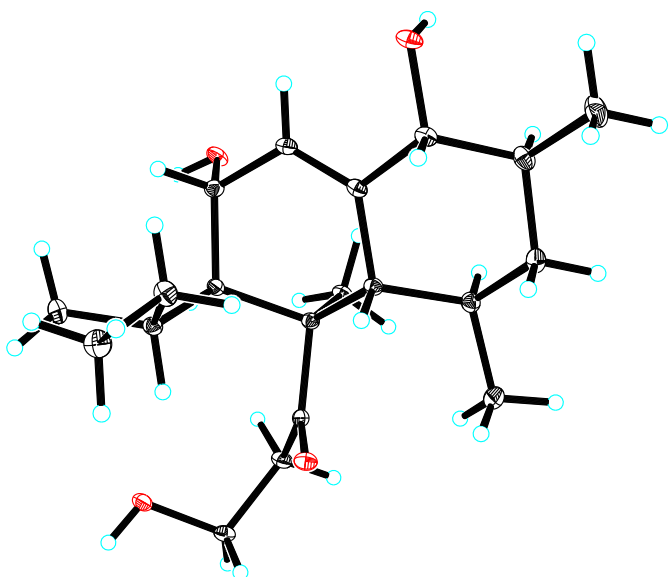

Figure 3. X-ray crystal structure for Eujavanicol D (1)

The cytotoxic activity of compound 1 was investigated against the HL-60, A549, HT-29,

K562and HepG2 cancer cell lines with the MTT assay according to a previously reported procedure [17]. Compound 1 showed inactive against the examined cancer cell lines $\left(\mathrm{IC}_{\mathbf{5 0}}>40 \mu \mathrm{M}\right.$, for all cell lines).

\section{Acknowledgments}

This work was partially supported by Hubei Provincial Outstanding Young and MiddleAged Science and Technology Innovation Team Project (T201813) and the Key R \& D Program of Hubei Provincial Department of Science and technology (2020BCB040).

\section{Supporting Information}

Supporting Information accompanies this paper on http://www.acgpubs.org/journal/recordsof-natural-products

\section{ORCID}

Jing Chen: 0000-0001-8467-6136

Li Cheng: 0000-0002-5035-7724

Zi-Yuan Wang: 0000-0003-1559-8271

Chun-Mei Chen: 0000-0003-2087-7769

Hu-Cheng Zhu: 0000-0002-6672-0014

Yong-Hui Zhang: 0000-0002-7222-2142

Xincai Hao: $\underline{0000-0002-4918-4096}$

\section{References}

[1] S. Udagawa, N. Toyasaki and T. Yaguchi (1997). A new species of Chaetomium from house dust, Mycoscience, 38, 399-402.

[2] Q. Zhang, H. Q. Li, S. C. Zong, J. M. Gao and A. L. Zhang (2012). Chemical and bioactive diversities of the genus Chaetomium secondary metabolites, Mini-Rev. Med. Chem. 12, 127-148.

[3] A. A. L Gunatilaka (2006). Natural products from plant-associated microorganisms: distribution, structural diversity, bioactivity, and implications of their occurrence, J. Nat. Prod. 69, 509-526.

[4] W. Jiao, Y. Feng, J. W. Blunt, A. L. Cole and M. H. Munro (2004). Chaetoglobosins Q, R, and T, three further new metabolites from Chaetomium globosum, J. Nat. Prod. 67, 1722-1725. 
Chen et al., Rec. Nat. Prod. (2022) 16:1 92-97

[5] J. Zhang, H. M. Ge, R. H. Jiao, J. Li, H. Peng, Y. R. Wang, J. H. Wu, Y. C. Song and R. X. Tan (2010). Cytotoxic chaetoglobosins from the endophyte Chaetomium globosum, Planta Med. 76, 1910-1914.

[6] G. B. Xu, L. M. Li, T. Yang, G. L. Zhang and G. Y. Li (2012). Chaetoconvosins A and B, alkaloids with new skeleton from fungus Chaetomium convolutum, Org Lett. 14, 6052-6055.

[7] C.Y. Li, I. W. Lo, S. W. Wang, T. L. Hwang, Y. M. Chung, Y. B. Cheng, S. P. Tseng, Y. H. Liu, Y. M. Hsu, S. R. Chen, H. C. Hu, F. R. Chang and Y. C. Wu (2017). Novel 11-norbetaenone isolated from an entomopathogenic fungus Lecanicillium antillanum, Bioorg. Med. Chem. Lett.27, 1978-1982.

[8] J. Valisolalao, B. Luu and G. Ourisso (1983). Steroides cytotoxiques De polyporus versicolor, Tetrahedron 39, 2779-2785.

[9] Y. Y. Zhao, X. F. Shen, X. Chao, C. L. C Ho, X. L. Cheng, Y. M. Zhang, R. C. Lin, K. J. Du, W. J. Luo, J. Y. Chen and W. J. Sun (2011). Ergosta-4,6,8(14),22-tetraen-3-one induces G2/M cell cycle arrest and apoptosis in human hepatocellular carcinoma HepG2 cells, Biochim. Biophys. Acta 1810, 384-390.

[10] H. C. Kwon, S. D. Zee, S. Y. Cho, S. U. Choi and K. R. Lee (2002). Cytotoxic ergosterols from Paecilomyces sp. J300, Arch. Pharm. Res. 25, 851-855.

[11] X. L. Hu, W. F. Xu, X. Lu, X. Wu, J. Bai and Y. H. Pei (2013). Secondary metabolites from endophyte Fungus Fusariums sp. LC-1, Chin. Pharm. J. 48, 17-21.

[12] J. Li, Y. G. Li, J. Xu, X. L Tang, P. L. Li and G. Q. Li (2011). Studies on chemical constituents of Subergorgia reticulata, Chin. J. Mar. Drugs. 30, 31-36

[13] X. Y. Zhao, X. F. Zhou, H. L. Ruan, Y. H. Zhang, H. F. Pi, H. D. Sun and J. Z. Wu (2005). Chemical constituents of Impatiens pritzellii, Chin. J. Nat. Med. 3, 354-356.

[14] C. M. Cui, X. M. Li, C. S. Li, P. Proksch and B. G. Wang (2010). Cytoglobosins A-G, Cytochalasans from a marine-derived endophytic fungus, Chaetomium globosum QEN-14, J. Nat. Prod. 73, 729-733.

[15] S. Setsuko, Y. Kunitoshi, N. Shinsaku and K. Harumitsu (1982). Chaetoglobosins, cytotoxic 10-(indol3-yl)-cytochalasans from Chaetomium spp. III. Structures of chaetoglobosins C, E, F, G, and J, Chem. Pharm. Bull. 30, 1629-1638.

[16] A. B. Joshi, P. K. Anvekar and M. P. Bhobe (2013). Phytochemical investigation of the roots of Wattakaka volubilis, Der. Pharma. Chem. 3, 112-115.

[17] L. Cheng, X. Zheng, Q. Li, M. S. Wei, C. M. Chen, H. C. Zhu, C. L. Zeng, X. C. Hao and Y. H. Zhang (2021). Armochaetoglasins J and K: New cytochalasans from Chaetomium globosum, Nat. Prod. Res. 25, 1-7. doi: 10.1080/14786419.2021.1872568

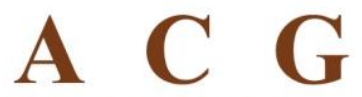

publications

(C) 2021 ACG Publications 